\title{
KAJIAN KOMUNIKASI PEMASARAN TERPADU DALAM MENDORONG \\ KEPUTUSAN PEMBELIAN JASA PERBANKAN
}

\author{
Popon Srisusilawati
}

\section{Universitas Islam Bandung Jl. Ranggagading No. 08 Bandung Jawa Barat Indonesia}

\author{
poponsrisusilawati@unisba.ac.id
}

\begin{abstract}
Abstrak
Konsep komunikasi pemasaran telah diatur oleh prinsip dasar pemasaran syariah, karena hal ini akan berpengaruh terhadap keputusan konsumen terhadap pembelian produk jasa perbankan. Penelitian ini untuk mengetahui tanggapan nasabah tentang pelaksanaan komunikasi pemasaran terpadu dan untuk mengetahui pengaruh komunikasi pemasaran terpadu dalam mendorong keputusan pembelian jasa perbankan. Dalam penelitian ini menggunakan metode deskriptif verifikatif. Pelaksanaan komunikasi pemasaran terpadu di PT. BRI KCP Bandung Ujung Berung secara umum tidak terlalu pilih-pilih media. Tanggapan nasabah tentang pelaksanaan komunikasi pemasaran terpadu menunjukkan responden yang setuju sebesar $42,73 \%$ hal ini menunjukkan bahwa mereka akan menjadi Nasabah pada PT. BRI KCP Bandung Ujung Berung Bandung dengan alasan mereka tertarik terhadap komunikasi pemasaran terpadu dan yang menjawab kurang setuju sebesar 56,12\% dengan alasan mereka kurang mengetahui tentang promosi yang diadakan oleh BRI Syariah.

Kata Kunci : Komunikasi Pemasaran, Keputusan Pembelian, Perbankan
\end{abstract}

\begin{abstract}
The concept of marketing communication has been governed by the basic principles of marketing Shariah because it will influence the consumer's decision to purchase the products of banking services. This study was to determine the response of customers regarding the implementation of integrated marketing communications and to determine the effect of integrated marketing communications services in driving purchasing decisions perbankan Dalam this research use descriptive method and verification.Implementation of integrated marketing communications at PT. BRI Syariah Branch Office Bandung Ujung Berung generally not too picky media. Customer feedback on the implementation of integrated marketing communications show respondents who agreed at $42,73 \%$ this indicates that they will become a customer at BRI Syariah Branch Ujung Berung Bandung with the reason they are attracted to integrated marketing communications and who answered disagree amounted to $56.12 \%$ with a reason they knew nothing of the sale held by BRI Syariah.
\end{abstract}

Keywords: Marketing Communication, Purchase Decision, Banking

Received: 2016-09-16 | Reviced: 2017-01-26 | Accepted: 2017-01-31

Indexed : DOAJ, Garuda, Crossref, Google Scholar |

DOI:https://doi.org/10.29313/amwaluna.v1i1.1993 


\section{PENDAHULUAN}

Di era Globalisasi sekarang ini, sebuah perusahaan harus mampu untuk mengikuti perubahan yang terjadi baik di dalam maupun di luar perusahaan.Untuk mengikuti perubahan-perubahan yang terjadi tersebut, bukanlah suatu hal yang mudah. Perusahaan yang cenderung berpikiran tradisional, tidak inovatif dan tidak mengharapkan adanya perubahan, tentu saja akan menemui banyak kesulitan dalam menjalankan operasinya.

Berbagai cara dan strategi dapat dilakukan oleh sebuah perusahaan dalam rangka mencapai keberhasilan dan kesuksesan yang ingin dicapainya. Strategi yang diterapkan perusahaan untuk tiap-tiap bidang di dalam pun berbeda-beda, mulai dari bagian produksi, distribusi, penjualan, maupun promosinya. Target perusahaan yang akan dicapai oleh suatu perusahaan tentunya harus didukung dengan adanya suatu strategi yang tepat agar perusahaan dapat mengalami peningkatan kualitas usahanya.

Strategi perusahaan dalam meningkatkan penjualannya dapat dilakukan dengan berbagai cara, salah satunya adalah dengan peningkatan strategi promosi, yang tentunya akan berdampak pada peningkatan biaya produksi. Tentu saja, cara-cara seperti ini diharapkan dapat mempengaruhi tingkat penjualan perusahaan secara signifikan.

Komunikasi pemasaran adalah salah satu kegiatan pemasaran yang berusaha menyebarkan informasi, mempengaruhi, dan atau meningkatkan pasar sasaran atas perusahaan maupun produk agar bersedia menerima, membeli, dan setia kepada produk yang ditawarkan produsen.

Pada kenyataannya, tidak semua konsumen mengetahui bagaimana cara untuk memenuhi kebutuhannya atau tidak menyadari adanya produk yang mampu memenuhi kebutuhannya. Konsumen mungkin akan aktif mencari informasi tersebut. Pada sisi lain, produsen menyadari situasi tersebut sehingga berusaha mengirim dan menyebarkan informasi tentang produk (adanya produk baru, manfaat dan kegunaan produk, harga, dimana dan kapan dapat dibeli, dan sebagainya) kepada mereka.

Meskipun telah mengetahui informasi (well informed), belum tentu konsumen akan memilih atau membeli kembali produk perusahaan (karena belum bersedia membeli sekarang, adanya produk lain yang sejenis, adanya barang pengganti, merasa harga terlalu mahal, kurang dapat mengetahui kebutuhan, dan sebagainya). Produsen perlu membujuk dan 
mengingatkan selalu mereka agar bersedia membeli atau memilih kembali produk perusahaan. Untuk semua itu, produsen perlu melakukan kegiatan promosi dengan berkomunikasi kepada konsumen. Karena, kegiatan promosi pada dasarnya adalah proses komunikasi antara produsen dengan konsumen, maka pemahaman komunikasi bagi produsen sangat diperlukan.

Komunikasi pemasaran terpadu adalah sebuah proses perencanaan marketing komunikasi yang memperkenalkan konsep perencanaan komprehensif untuk mengevaluasi peranan strategis dari berbagai elemen komunikasi pemasaran, seperti public relation, advertising, direct selling, sales promotion, dan interactive marketing, untuk memberikan kejelasan, konsistensi, serta pengaruh komunikasi yang maksimum. Komunikasi Pemasaran Terpadu sering disebut dengan IMC merupakan sebuah proses strategi bisnis dalam mengelola hubungan dengan konsumen yang intinya untuk menggerakkan brand value. Tujuan Integrated Marketing Communication (IMC) adalah mempengaruhi atau memberikan efek langsung kepada perilaku khalayak sasaran. (Ardianto, 2004)

Keputusan pembelian sebagai efek langsung dari komunikasi pemasaran terpadu merupakan tahap dalam proses pengambilan keputusan pembeli di mana konsumen benar-benar membeli. Pengambilan keputusan merupakan suatu kegiatan individu yang secara langsung terlibat dalam mendapatkan dan mempergunakan barang yang ditawarkan. Dalam keputusan pembelian terdapat beberapa tahap yang tidak selalu sesuai dengan urutannya, antara lain: pengenalan masalah, pencarian informasi, evaluasi alternatif, keputusan pembelian, dan perilaku setelah pembelian (Kusuma, 2014). (N, T, \& Tresnati, 2015)

Berkaitan dengan konsep komunikasi pemasaran ini, dalam ajaran Islam telah diatur prinsip-prinsip dasar pemasaran agar proses pemasaran yang dilakukan sesuai dengan aturan syariah yang telah ditentukan, karena hal ini akan berpengaruh terhadap keputusan konsumen terhadap pembelian produk jasa perbankan. (Daud, 2013) (I, 2015)

Berdasarkan latar belakang masalah di atas, maka penulis merumuskan bagaimanakah pelaksanaan komunikasi pemasaran terpadu di PT. BRI Syariah KCP Ujung Berung Bandung, bagaimanakah tanggapan nasabah tentang pelaksanaan komunikasi pemasaran terpadu di PT. BRI Syariah KCP Ujung Berung Bandung dan seberapa besar pengaruh komunikasi pemasaran terpadu dalam mendorong keputusan pembelian jasa 
perbankan di PT. BRI Syariah KCP Ujung Berung Bandung.

Berdasarkan pada rumusan masalah di atas, maka tujuan penelitian adalah untuk mengetahui pelaksanaan komunikasi pemasaran terpadu di PT. BRI Syariah KCP Ujung Berung Bandung, untuk mengetahui tanggapan nasabah tentang pelaksanaan komunikasi pemasaran terpadu di PT. BRI Syariah KCP Ujung Berung Bandung dan untuk mengetahui pengaruh komunikasi pemasaran terpadu dalam mendorong keputusan pembelian jasa perbankan di BRI Syariah KCP Ujung Berung Bandung.

Dalam penelitian ini menggunakan metode deskriptif verifikatif, yaitu menganalisa data dengan cara mendeskripsikan atau menggambarkan data yang telah terkumpul sebagaimana adanya tanpa bermaksud membuat kesimpulan yang berlaku untuk umum atau generalisasi. Analisa deskriptif berfungsi untuk menggambarkan data-data dan responden, analisa deskriptif ditampilkan dalam distribusi frekuensi dan persentase.

\section{PEMBAHASAN}

Persaingan usaha yang ketat membuat perusahaan harus selalu siap dan terampil dalam menerapkan strategi dan kebijakan perusahaan yang biasa disebut sebagai bauran pemasaran. Pengertian bauran pemasaran adalah strategi mencampur kegiatan-kegiatan pemasaran untuk mencari kombinasi maksimum sehingga mendapatkan hasil yang memuaskan.Bauran pemasaran ini terdiri atas 4P, yaitu product, place, price, dan promotion. (hasan, 2010)

Promosi (promotion) adalah bagaimana produk yang kita pasarkan itu diketahui oleh konsumen. Yang perlu disampaikan/dikenalkan kepada konsumen adalah manfaat produk, harga produk, bagaimana cara membelinya dimana bisa didapat dan apa daya tarik produk tersebut (wahjono, 2010)

Promosi merupakan salah satu bentuk komunikasi pemasaran, sedangkan komunikasi pemasaran itu sendiri adalah aktivitas pemasaran yang berusaha menyebarkan informasi, mempengaruhi, atau membujuk, dan kemudian meningkatkan pasar sasaran atas perusahaan dan produknya, agar konsumen bersedia menerima, membeli, dan setia pada produk yang ditawarkan oleh perusahaan yang bersangkutan. (Tjiptono, 2008)

Menurut Etri Haryanti penentuan marketing mix yang ditujukan agar setiap kegiatan pemasaran dapat berlangsung 
dengan sukses, produknya dikembangkan sesuai dengan kebutuhan dan keinginan konsumen, diberi harga yang terjangkau oleh konsumen lalu didistribusikan, dimana kosumen bisa belanja dan dipromosikan melalui media yang terjangkau konsumen. Bauran pemasaran (marketing mix) merupakan alat bagi pemasar yang terdiri atas berbagai unsur suatu program pemasaran yang perlu dipertimbangkan agar implementasi strategi pemasaran dan positioning yang ditetapkan dapat berjalan sukses. Karena merupakan unsur suatu program pemasaran yang dikendalikan perusahaan untuk mengontrol pasar sasaran yang diingikan (Haryanti, 2014)

Bauran pemasaran merupakan seperangkat alat pemasaran yang digunakan perusahaan untuk mencapai tujuan pemasaran dalam memenuhi target pasarnya.

Bauran pemasaran memilki 4 (empat) variabel yang dikenal dengan istilah " $4 \mathrm{P}$ " (product, price, promotion, and place). Sedangan pada jasa ditambahkan manjadi “3P” (people, process, and physical evidence) Yang saling berkaitan satu sama lain. Jadi terdapat "7P" Variabel-variabel dalam bauran pemasaran dapat diuraikan sebagai berikut: (Tjiptono, 2008)

\section{a. Produk (Product)}

Produk adalah segala sesuatu yang dapat ditawarkan kepada pasar untuk dapat diperhatikan, diperoleh digunakan untuk dikonsumsi sehingga dapat memenuhi kebutuhan dan keinginan konsumen.

\section{b.Harga (Price)}

Harga merupakan jumlah uang yang harus dibayarkan oleh konsumen untuk mendapatkan suatu produk. Harga diukur dengan nilai yang dirasakan dari produk yang ditawarkan jika tidak maka konsumen akan membeli produk lain dengan kualitas yang sama dari penjualan saingannya. Harga adalah satu-satunya alat bauran pemasaran yang digunakan perusahaan untuk mencapai sasaran pemasarannya. Keputusan harga harus dikoordinasikan dengan rancangan produk, distribusi dan promosi yang membentuk program pemasaran yang konsisten dan efektif.

\section{c.Promosi (Promotion)}


Promosi merupakan kegiatan yang Maksud dari physical evidence adalah dilakukan oleh perusahaan untuk penampilan fisik tenaga penjual. Peran dan mengkomunikasikan manfaat dari produk penampilan tenaga penjual bagi perusahaan atau jasa dan meyakinkan konsumen yang menggunakan system personal selling sasaran tentang produk yang mereka sangatlah penting. Mereka berfungsi hasilkan.

\section{d.Tempat (Place)}

Tempat termasuk aktivitas perusahaan untuk membuat produk tersedia bagi konsumen sasaran. Keputusan mengenai tempat yang sangat penting agar konsumen dapat memperoleh produk yang dibutuhkan tepat pada saat yang dibutuhkan.

e.People

Dibutuhkan seorang tenaga penjualan yang memiliki kemampuan berkomunikasi dan product knowledge yang baik selain bermental baja, kreatif, ulet, ramah dan jujur.

\section{f. Process}

Proses di mulai dari mencari calon konsumen sampai dengan penyampaian jasa berupa produk kepada konsumen.

\section{g. Physical Evidence} sebagai tenaga ahli penjualan yang bertatap muka langsung dengan konsumen.

Konsep pengembangan strategi pemasaran berkaitan dengan masalah bagaimana menetapkan bentuk penawaran pada segmen pasar tertentu. Hal ini dapat terpenuhi dengan penyediaan suatu sarana yang disebut bauran pemasaran, yang sering juga disebut sebagai basis strategi, yang mencakup produk, harga, distribusi dan komunikasi pemasaran. (hasan, 2010)

Gagasan Mega Marketing, yaitu dengan memasukkan unsur dua "P" baru. Bila sebelumnya hanya "4P" (Product Price. Place, Promotions), maka dua unsur tambahan tersebut adalah(Power dan Public Relations), sehingga selanjutnya menjadi formula 6P (Kotler \& Lane, Marketing Managent , edisi 13, 2009). Artinya untuk pola 4P itu sifatnya konvensial, mudah dikontrol karena korelasi atau hubungan komponen yang berwujud dan dapat diukur. Sedangkan untuk 2P (power) yaitu kekuatan opini, 
persepsi, tanggapan, dan tujuan yang hendak dicapai oleh PR sulit diukur dan masalah citra atau kepercayaan itu hasilnya sulit untuk diketahui tolok ukurnya dan sulit dikontrol karena bersifat kualitatif (Ardianto, 2004)

Komunikasi pemasaran adalah sarana yang digunakan perusahaan dalam upaya untuk menginformasikan, membujuk dan mengingatkian konsumen baik secara langsung maupun tidak langsung tentang produk dan merek yang mereka jual. Sedangkan, Menurut Terence A. Shimp, komunikasi pemasaran terpadu atau yang lebih dikenal dengan Integrated Marketing Communication (IMC) adalah proses pengembangan dan implementasi berbagai bentuk program komunikasi persuasif kepada pelanggan dan calon pelanggan secara berkelanjutan (Terence A Shimp. 2003). Tujuan Integrated Marketing Communication (IMC) adalah mempengaruhi atau memberikan efek langsung kepada perilaku khalayak sasaran yang dimilkinya. Integrated Marketing Communication (IMC) menganggap seluruh sumber yang dapat menghubungkan pelanggan atau calon pelanggan dengan produk atau jasa dari suatu merek atau perusahaan, adalah jalur yang potensial untuk menyampaikan pesan di masa datang. Lebih jauh lagi, Integrated Marketing Communication (IMC) menggunakan semua bentuk komunikasi yang relevan serta yang dapat diterima oleh pelanggan dan calon pelanggan. Dengan kata lain, proses Integrated Marketing Communication (IMC) berawal dari pelanggan atau calon pelanggan, kemudian berbalik kepada perusahaan untuk menentukan dan mendefinisikan bentuk dan metode yang perlu dikembangkan bagi program komunikasi yang persuasif.

Komunikasi pemasaran terpadu atau yang dikenal dengan Integrated Marketing Communication (IMC) adalah sebuah konsep dari perencanaan komunikasi pemasaran yang memperkenalkan nilai tambah dari rencana komprehensif yang mengevaluasi peran strategis dari berbagai disiplin komunikasi, misalnya periklanan umum, respon langsung, sales promotion, dan PR dan mengombinasikan disiplindisiplin ini untuk memberikan kejelasan, konsistensi dan dampak komunikasi yang maksimal.

Secara sederhananya Integrated Marketing Communication (IMC) dapat diartikan sebagai "Proses dari pengelolaan customer relationships yang menggerakkan 
brandvalue". Sedangkan secara spesifik, Integrated Marketing Communication (IMC) dapat diartikan sebagai "Proses yang mempunyai fungsi bersilang dalam menciptakan dan memelihara hubungan yang menguntungkan dengan customer dan stakeholder lainnya dengan mengontrol dan mempengaruhi secara strategis semua pesan yang terkirim kepada kelompok ini serta menggerakkan dialog dengan maksud tertentu kepada mereka".

Intergrated Marketing

Communication (IMC) adalah satu dari sekian proses yang tersedia guna membina hubungan dengan customer. Apa yang membedakan Intergrated Marketing Communication (IMC) dengan proses customer-centric lainnya adalah dasar dari proses tersebut adalah komunikasi, yang merupakan jantung dari semua hubungan, dan juga merupakan proses yang sirkuler.

Komunikasi pemasaran mempunyai beberapa fungsi yaitu sebagai berikut: a. Konsumen dapat diberitahu atau ditunjukkan bagaimana dan mengapa sebuah produk digunakan. Selain itu juga member tahu dimana serta kapan produk tersebut digunakan.

b. Konsumen dapat mengetahui tentang siapa yang membuat produk tersebut dan apa keunggulan produk tersebut dibandingkan produk lain yang sejenis.

Kotler menyebutkan bahwa dewasa ini terdapat suatu pandangan baru yang memandang komunikasi sebagai dialog interaktif antara perusahaan dengan pelanggannya yang berlangsung selama tahap prapenjualan, penjualan, konsumsi, dan pasca konsumsi. Proses komunikasi harus berjalan seefektif mungkin agar tujuan komunikasi yang telah ditetapkan dapat tercapai (Kotler, Manajemen Pemasaran, Edisi 12 Jilid 1 Satu, 2007)

Elemen-elemen dalam proses komunikasi dibagi menjadi sembilan unsur. Dua unsur diantaranya adalah pihak utama dalam komunikasi yaitu pengirim dan 
penerima, dua unsur selanjutnya adalah alat komunikasi utama, pesan dan media, sementara empat unsur selanjutnya merupakan fungsi komunikasi utama pengkodean (encoding), penguraian kode (decoding), tanggapan (response), dan umpan balik (feedback). Unsur terakhir dalam sistem tersebut adalah gangguan (noise) yaitu pesan-pesan acak dan bertentangan yang dapat mengganggu komunikasi yang diharapkan.

Proses komunikasi dimulai ketika pengirim mengirimkan pesan. Pengirim harus mengetahui siapa yang ingin dicapai dan tanggapan apa yang diinginkan pengirim dalam hal ini perusahaan yang mengirimkan pesan tentang produk yang telah dihasilkannya kepada pelanggannya. Pesan ini disampaikan dengan kode-kode yang sesuai dengan sasaran pelanggannya melalui media-media yang ada.

Perusahaan sebagai pengirim pesan harus mengirimkan pesan yang sesuai guna untuk mencapai pelanggan sasaran dan membangun umpan balik untuk memantau tanggapan dari para pelanggan atas pesan tersebut. Hal ini bertujuan agar penyampaian pesan ini efektif, maka pesan harus disampaikan dengan kode-kode yang dapat dikenali oleh pelanggan.

Kotler menjelaskan kedelapan tahap tahap dalam mengembangkan komunikasi yang efektif antara lain sebagai berikut: (Kotler, Manajemen Pemasaran, Edisi 12 Jilid 1 Satu, 2007)

1. Identifikasilah Audiens Sasaran

Proses tersebut haruslah dimulai dengan audiens sasaran yang jelas dalam benak calon pembeli produk perusahaan tersebut, pemakai sekarang, penentu kebijakan, atau pihak yang mempengaruhi; orang $\quad-\quad$ orang, kelompok, masyarakat tertentu, atau masyarakat umum. Pendengar sasaran tersebut akan mempengaruhi keputusan komunikator tentang apa yang harus dikatakan, bagaimana mengatakannya, kapan mengatakannya, di mana mengatakannya, dan kepada siapa mengatakannya. 
2. Menentukan Tujuan Komunikasi

Tujuan komunikasi dapat ditetapkan pada tingkat mana saja dari model hirarki efek. Rossister dan Percy mengindentifikasi empat kemungkinan tujuan sebagai berikut:

a. Kebutuhan kategori

Membangun produk atau kategori layanan sejauh perlu untuk membuang atau memenuhi kesenjangan yang dirasakan antara situasi motivasi sekarang dan situasi emosional yang diinginkan.

b. Kesadaran merek

Kemampuan untuk mengidentifikasi (mengakui atau mengingat) merek dalam kategori, secara cukup rinci untuk melakukan pembelian.

c. Sikap merek

Evaluasi merek dengan menghargai kemampuannya yang dirasakan untuk memenuhi kebutuhan yang relevan sekarang ini

d. Maksud pembelian merek
Intruksi untuk membeli merek atau melakukan tindakan yang berkaitan dengan pembelian. Tawaran promosi dalam bentuk kupon atau beli dua dapat gratis satu mendorong konsumen untuk melakukan komitmen dalam pikiran guna membeli produk.

3. Merancang komunikasi

Merumuskan komunikasi untuk mencapai tanggapan yang diinginkan akan menuntut pemecahan tiga masalah : apa yang harus dikatakan (strategi pesan), bagaimana mengatakannya (strategi kreatif), dan siapa yang harus mengatakannya (sumber pesan).

a. Strategi pesan

Dalam menentukan strategi pesan, manajemen mencari daya tarik, tema, atau gagasan yang akan mengikat ke dalam penentuan posisi merek, dan membantu untuk membanguntitik kesamaan atau titik perbedaan. Beberapa 
darinya mungkin berkaitan langsung dengan kinerja produk atau jasa (mutu penghematan atau nilai merek) sementara yang lain berkaitan dengan pertimbangan - pertimbangan yang lebih ekstrinsik (mereknya bersifat kontemporer, populer, atau tradisional).

\section{b. Strategi kreatif}

Efektifitas komunikasi tergantung pada bagaimana pesan diekspresikan dan juga isi pesan itu sendiri. Komunikasi yang tidak efektif bisa berarti bahwa pesan yang salah digunakan atau pesan yang benar tidak diekspresikan dengan baik. Strategi kreatif adalah cara pemasar menerjemahkan pesan mereka ke dalam satu komunikasi yang spesifik. Strategi kreatif dapat diklasifikasikan secara luas sebagai meliputi daya tarik “informasional"atau "transformasional". Dua kategori umum ini masingmasingnya mencakup beberapa pendekatan kreatif spesifik yang berbeda.

c. Sumber pesan
Banyak komunikasi tidak menggunakan satu sumber lebih jauh dari perusahaan itu sendiri. Yang lain menggunakan orang yang dikenal atau tidak dikenal. Pesan yang disampaikan sumber yang menarik atau terkenal akan memperoleh perhatian dan daya ingat yang lebih tinggi. Itulah sebabnya pemasang iklan sering menggunakan selebriti sebagai juru bicara. Selebriti kemungkinan akan efektif apabila mereka melambangkan ciri utama produk.

4. Pilihlah saluran komunikasinya Menyeleksi saluran yang efisien untuk menyampaikan pesan menjadi lebih sulit katika saluran komunikasi menjadi lebih terpotong-potong, saluran komunikasi dapat bersifat pribadi dan non-pribadi.

personal communication channel melibatkan dua atau beberapa orang yang berkomunikasi langsung satu sama lain dengan tatap muka, satu orang dengan audiens, melalui telepon, atau melalui email. Saluran komunikasi pribadi 
memperoleh efektifitasnya melalui baru telah tumbuh dan konsumen sudah presentasi dan umpan balik yang bersifat makin canggih. Begitu luasnya jenis alat perorangan. komunikasi, pesan, dan pendengar telah

Komunikasi pemasaran terpadu atau yang dikenal IMC (integrated marketing communication) adalah konsep perencanaan komunikasi pemasaran yang mengakui nilai tambah suatu rencana yang komprehensif. Rencana semacam itu mengevaluasi peran strategi berbagai disiplin komunikasi, misalnya iklan umum, tanggapan langsung, promosi penjualan, dan hubungan masyarakat serta menggabungkan disiplin-disiplin ini untuk memberikan kejelasan. Konsistensi dan pengaruh maksimum melalui integrasi pesan-pesan yang saling berlainan secara mulus. Sayangnya, banyak perusahaan masih mengandalkan satu atau dua alat komunikasi. Praktik ini terus dipertahankan meskipun pasar massal telah terpecahpecah menjadi begitu banyak pasar kecil, yang masing-masing memerlukan pendekatannya tersendiri. Jenis-jenis media membawa keharusan agar perusahaanperusahaaan beralih ke arah komunikasi pemasaran terpadu.

Proses dari komunikasi pemasaran memiliki elemen-elemen yang dapat dibagi menjadi sembilan unsur. Dua unsur diantaranya adalah pihak utama dalam komunikasi, yaitu pengirim dan penerima, dua unsur selanjutnya adalah alat komunikasi utama, pesan dan media, sementara empat unsur selanjutnya merupakan fungsi komunikasi utama pengkodean (encoding), penguraian kode (decoding), tanggapan (response), dan umpan balik (feedback).Unsur terakhir dalam sistem tersebut adalah gangguan (noise), yaitu pesan-pesan acak dan bertentangan yang dapat mengganggu komunikasi yang diharapkan. Proses komunikasi dimulai ketika pengirim mengirimkan pesan. Pengirim harus mengetahui siapa yang ingin dituju dan tanggapan apa yang diinginkan. Pengirim dalam hal ini perusahaan - mengirimkan pesan tentang produk yang telah dihasilkannya kepada pelanggannya. 
Mengembangkan

suatu

komunikasi pemasaran yang efektif dapat melalui beberapa tahapan-tahapan, antara lain: mengidentifikasi pendengar sasaran, menentukan tujuan-tujuannya, memilih salurannya, menetapkan anggarannya, merancang pesannya, memutuskan bauran media yang dipilih, mengukur hasilnya, dan mengelola komunikasi pemasaran.

Menurut Kotler alat-alat yang digunakan dalam komunikasi pemasaran ada 8 (delapan), diantaranya: advertising, sales promotion, event and experince, public relation and publicity, personal selling, direct marketing, word of mouth marketing, and interactive marketing. (Kotler, Manajemen Pemasaran, Edisi 12 Jilid 1 Satu, 2007)

Seiring dengan berkembangnya ilmu pengetahuan, muncullah suatu tren aplikasi yang dinamakan komunikasi pemasaran terpadu (integrated marketing communication). Tren ini menjadi salah satu bagian yang penting dalam kegiatan pemasaran yang dilakukan perusahaanperusahaan sekarang ini.

Komunikasi pemasaran terpadu atau Integrated Marketing Communication (IMC), menurut Shimp adalah proses pengembangan dan implementasi berbagai bentuk komunikasi persuasif kepada pelanggan dan calon pelanggan secara berkelanjutan. Tujuan Integrated Marketing
Communication (IMC) adalah mempengaruhi atau memberikan efek langsung kepada perilaku khalayak sasaran (Shimp, 2003)

Keputusan pembelian sebagai efek dari IMC terhadap perilaku khalayak sasaran (konsumen) sangat dipengaruhi oleh berbagai faktor, diantaranya faktor kebudayaan, sosial, pribadi, dan psikologi dari konsumen. Selain itu juga dipengaruhi oleh beberapa rangsangan pemasaran, seperti unsur-unsur di dalam bauran pemasaran, yaitu produk, harga distribusi, dan promosi serta rangsangan lainnya, yaitu perekonomian, teknologi, politik dan budaya.Sebagian besar faktor-faktor tersebut adalah faktor-faktor yang tidak dapat dikendalikan oleh pemasar, tetapi harus benar-benar dapat diperhitungkan. (wahjono, 2010) (Yuliana, Hidayat, \& Tresnati, 2016)

Kebijakan komunikasi pemasaran yang efektif dan efisien merupakan hal penting dalam menarik nasabah. Pelaksanaan komunikasi pemasaran yang dilakukan oleh BJB Syariah mengacu beberapa aspek yaitu : Advertising, promosi penjualandan pengalaman. $(\mathrm{N}, \mathrm{T}, \&$ Tresnati, 2015)

Saluran distribusi, pembisnis muslim sekali-kali tidak akan pernah melakukan tindak kezaliman terhadap pesaing lain, suap untuk melicinkan saluran 
pasarnya dan tindakan lain. Pada promosi, pebisnis muslim juga akan menghindari iklan promo, bohong dan promosi yang menghalalkan segala cara (Yusanto \& Widjajakusuma, 2012)

Tahap-tahap proses keputusan pembelian dapat digambarkan dalam sebuah model yaitu: pengenalan kebutuhan, pencarian informasi, evaluasi alternatif, keputusan pembelian, dan perilaku setelah pembelian. Kelima tahapan tersebut tidak selalu digunakan dalam keputusan pembelian, khusunya dalam keputusan pembelian yang berskala kecil. Oleh karena itu, para konsumen dapat menggunakan tahapan-tahapan tersebut secara acak dan tidak berurutan.

Dalam pandangan Islam, proses komunikasi pemasaran dan keputusan pembelian sebagaimana telah dijelaskan di atas adalah salah satu kegiatan muamalah yang dibenarkan, selama proses dalam kegiatan muamalah tersebut terpelihara dari hal-hal yang dilarang oleh ketentuan syariah, seperti penipuan, kebohongan, dan lain sebagainya. Berkaitan dengan hal tersebut, Islam dalam syari'ah-nya telah mengatur prinsip-prinsip dasar yang harus dilakukan para pelakunya dalam kegiatan tersebut, antara lain sebagaimana dijelaskan dalam sabda Raulullah Saw.:
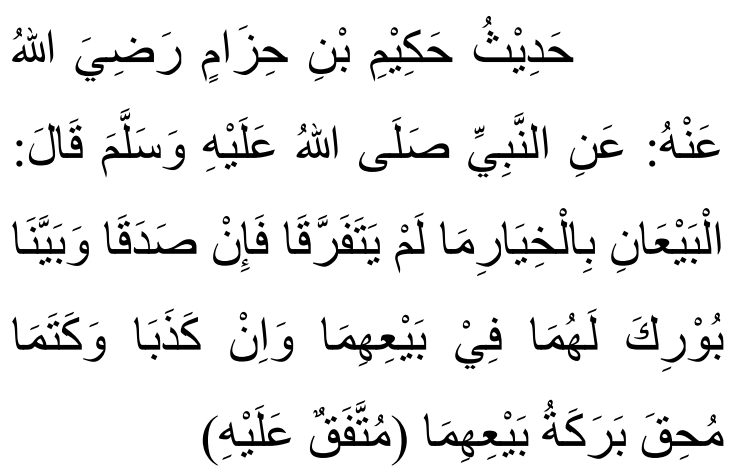

"Diriwayatkan dari Hakim bin Hizam r.a., dia berkata: dari Rasulullah Saw. bahwa beliau telah bersabda: 'penjual dan pembeli diberi kesempatan berpikir selagi mereka belum berpisah. Sekiranya mereka jujur serta membuat penjelasan mengenai barang yang diperjualbelikan, mereka akan mendapat berkah dalam jual beli mereka. Sekiranya mereka menipu dan merahasiakan mengenai apa-apa yang harus diterangkan tentang barang yang diperjualbelikan, maka akan terhapus keberkahannya", (Mahalli \& Hasbullah, 2004)

Hadis di atas menerangkan bahwa dalam proses pemasaran (penjual), hendaklah seorang marketer harus memberikan penjelasan yang sejujurjujurnya mengenai produk yang ditawarkan tanpa ada informasi yang disembunyikan dan dirahasiakan, sehingga tidak ada pihakpihak yang merasa tertipu dalam transaksi tersebut. Apabila penjual (marketer) menipu atau merahasiakan tentang apa 
yang seharusnya dikatakan, maka tidak akan mendapatkan manfaat dari transaksinya. Hal-hal seperti inilah yang harus selalu harus diperhatikan oleh para pelaku, agar mendapatkan berkah dari Allah Swt. atas transaksi yang dilakukan.

Secara umum pemasaran syariah adalah sebuah disiplin bisnis strategi yang mengarahkan proses penciptaan, penawaran dan perubahan value dari inisiator kepaa stake holdernya yang dalam keseluruhan prosesnya sesuai dengan akad dan prinsip-prinsip muamalah dalam Islam. Artinya dalam pemasaran syariah, seluruh proses, baik proses penciptaan, proses penawaran maupun proses perubahan nilai tidak boleh ada yang bertentangan dengan primsif syariah . ada 4 karakter yang terdapat pada syariah marketing yaitu ketuhanan (rabbaniyah) , etis (akhlaqiyyah), realistis (alwaqiyyah) dan humanistis. (insaniyyah) (Yusanto \& Widjajakusuma, 2012) (Al Arif, 2010)

Pesan yang disampaikan lewat iklan PT. BRI Syariah Bandung mengandung informasi yang penting untuk diketahui oleh konsumennya.Format pesan merupakan faktor penting yang menentukan menarik atau tidaknya pesan dalam suatu iklan. Format pesan iklan PT. BRI Syariah Bandung yang akan diterangkan penulis disini adalah penggunaan poster sebagai alat untuk merangsang pembelian dengan segera dan untuk mensosialisasikan program promosi Komunikasi Pemasaran Terpadu. Tampilan poster yang unik berbentuk lingkaran merupakan daya tarik sendiri dalam promosi Komunikasi Pemasaran Terpadu. Pada tampilan poster tersebut, secara jelas diberikan penjelasan kapan promosi dimulai, mekanisme promosi, bagaimana cara mendapatkan hadiah, hadiah apa saja yang bisa didapatkan konsumen, alamat Sales Center/tempat penukaran hadiah serta dicantumkan pula peraturan dan ketentuan promosi Komunikasi Pemasaran Terpadu. Dengan hanya membaca poster yang telah dipasang pada outlet-outlet, kios ataupun warung diharapkan dapat menarik minat peserta/konsumen untuk ikut dalam promosi Komunikasi Pemasaran Terpadu yang diberikan PT. BRI Syariah Bandung.

Seorang komunikator mempunyai kemampuan untuk melakukan perubahan sikap, pendapat dan tingkah laku komunikasi melalui mekanisme daya tarik jika pihak komunikan merasa bahwa komunikator ikut serta denganya. Untuk menghasilkan perubahan sikap yang diinginkan, public relations menggunakan saluran media massa. Sebagai sarana komunikasi, berbagai bentuk media massa, seperti surat kabar, radio, televisi sangat menentukan dalam perubahan sikap seseorang. Sedangkan berdasarkan 
penelitian Riska bahwa upaya untuk meningkatkan jumlah uzzaki yaitu dengan mengoptimalkan alat promosi yang digunakan serta menjalin kerjasama dengan corporate lainnya (Yuliana, Hidayat, \& Tresnati, 2016).

Dalam membentuk opini tergantung bagaimana manajemen yang membawahi unit pemasaran di PT. BRI Syariah Bandung dapat menangkal semua pernyataan negatif dari para konsumennya mengenai produk-produk PT. BRI Syariah Bandung, apalagi dengan diadakannya program promosi Komunikasi Pemasaran Terpadu.

Maka untuk mengukur atau mengetahui bagaimana hubungan antara kedua variabel tersebut, diperlukan suatu alat analisis statistik dengan metode koefisien korelasi Rank Spearman dengan bantuan software SPSS for Windows versi 22. Dimana komunikasi pemasaran terpadu sebagai variabel $X$ menggunakan 15 pertanyaan dan keputusan menjadi nasabah sebagai variabel $\mathrm{Y}$ menggunakan 2 pertanyaan sebagai indikatornya, semua pertanyaan tersebut telah melalui uji validitas dan reliabilitas.

Untuk mengetahui hubungan kedua variabel, penulis menggunakan alat bantu software SPSS for Windows versi 22 dengan tingkat kepercayaan $0,05 \quad(5 \%)$, dimana hasilnya untuk tingkat signifikansi sebesar 0,000 dan koefisien korelasi $\left(\mathrm{r}_{\mathrm{s}}\right)$ adalah sebesar 0,628. Untuk koefisien korelasi yang besarnya 0,628 menurut kategori dalam derajat hubungan dan penafsiran termasuk kedalam kategori hubungan positif yang tinggi. Artinya pada BRI Syariah KCP Ujung Berung Bandung, keputusan untuk menjadi nasabah dibentuk oleh komunikasi pemasaran terpadu yang dilakukan pihak BRI Syariah KCP Ujung Berung Bandung. Adapun tanda positif $(+)$ pada korelasi menggambarkan bahwa jika komunikasi pemasaran terpadu meningkat maka keputusan menjadi nasabah akan semakin banyak dan jika komunikasi pemasaran terpadu menurun maka keputusan untuk menjadi nasabah juga akan menurun.

Untuk pengujian apakah terdapat korelasi antara variabel bebas dan variabel tidak bebas dilakukan pengujian hipotesis yaitu :

$\mathrm{H}_{0}$ : Tidak terdapat hubungan antara komunikasi pemasaran terpadu dengan keputusan menjadi nasabah BRI Syariah KCP Ujung Berung Bandung.

$\mathrm{H}_{\mathrm{a}}$ : Terdapat hubungan antara komunikasi pemasaran terpadu dengan keputusan 
menjadi nasabah BRI Syariah KCP

Ujung Berung Bandung.

Untuk menguji kebenaran hipotesis, maka digunakan uji-t dengan ketentuan :

Jika $\mathrm{t}$ hitung $>\mathrm{t}$ diagram maka $\mathrm{H}_{0}$ ditolak.

Jika t hitung $<\mathrm{t}$ diagram maka $\mathrm{H}_{0}$ diterima.

Nilai $t$ hitung dapat dicari dengan cara menggunakan rumus:

$$
\begin{aligned}
t & =r_{s} \sqrt{\frac{n-2}{1-r_{s}^{2}}} \\
& =0,628 \sqrt{\frac{99-2}{1-(0,628)^{2}}} \\
& =0,628 \sqrt{\frac{97}{0,6065}} \\
& =0,628 \times 12,59 \\
& =7,91
\end{aligned}
$$

Setelah dilakukan uji t, maka dihasilkan untuk t hitung sebesar 7,91 lebih besar dari $\mathrm{t}$ diagram 1,6609. Kriteria $\mathrm{t}$ hitung $>\mathrm{t}$ diagram $(7,91>1,6609)$ menunjukkan bahwa $\mathrm{H}_{0}$ ditolak, yang berarti terdapat hubungan antara pelaksanaan komunikasi pemasaran terpadu dengan keputusan menjadi nasabah PT. BRI KCP Ujung Berung Bandung.

\section{SIMPULAN}

Pelaksanaan komunikasi pemasaran terpadu di PT. BRI Syariah KCP Ujung Berung Bandung secara umum menentukan jenis media yang digunakan dalam program promosi Komunikasi Pemasaran Terpadu antara lain sebagai berikut :Periklanan, Promosi penjualan, Acara khusus dan pengalaman, Hubungan masyarakat dan pemberitaan, Penjualan perorangan (personal selling), Pemasaran langsung dan Pemasaran dari mulut ke mulut.

Tanggapan nasabah tentang pelaksanaan komunikasi pemasaran terpadu di PT. BRI Syariah KCP Ujung Berung Bandung menunjukkan responden yang menjawab setuju sebesar $42,73 \%$ hal ini menunjukkan bahwa mereka akan menjadi Nasabah pada PT. BRI KCP Ujung Berung Bandung dengan alasan mereka tertarik terhadap komunikasi pemasaran terpadu yang dilakukan oleh BRI Syariah.

Pengaruh komunikasi pemasaran terpadu dalam mendorong keputusan pembelian jasa perbankan di BRI Syariah KCP Ujung Berung Bandung adalah setelah dilakukan uji t, maka dihasilkan untuk t hitung sebesar 7,91 lebih besar dari $\mathrm{t}$ diagram 1,6609. Kriteria $\mathrm{t}$ hitung $>\mathrm{t}$ diagram $(7,91>1,6609)$ menunjukkan bahwa $\mathrm{H}_{0}$ ditolak, yang berarti terdapat pengaruh antara pelaksanaan komunikasi 
Popon Srisusilawati, Kajian Komunikasi Pemasaran Terpadu Dalam Mendorong Keputusan

pemasaran terpadu dengan keputusan menjadi nasabah PT. BRI KCP Ujung Berung Bandung.

\section{DAFTAR PUSTAKA}

Al Arif, N. R. (2010). Dasar-dasar pemasaran bank Syariah . Bandung: Alfabeta.

Ardianto, E. (2004). Public Relations Suatu pendekatan Praktis. Bandung:

Pustaka Bani Quraisy.

Daud, D. (2013). Promosi dan kualitas layanan pengaruhnya terhadap keputusan konsumen menggunakan jasa pembiayaan pada PT. Bess Finance Manado. Jurnal EMBA: Jurnal Riset Ekonomi, Manajemen, Bisnis dan Akuntansi, 1(4).

Haryanti, I. E. (2014). Pengaruh Bauran Pemasaran Terhadap Keputusan Nasabah Dalam Memilih BPR Syariah Tanmiya Artha Kediri. sskripsi repo.iain-tulungagung.

hasan, A. (2010). Marketing Bank Syariah Cara Jitu Meningkatkan Bank Syariah. Bogor: Ghalia.

I, A. B. (2015). Pengaruh Citra Merek dan Promosi Penjualan Terhadap Keputusan Nasabah Memilih Tabungan Bank Syariah Mandiri. Jurnal Ilmu Manajemen (JIM), 2(4).

Kotler, P. (2007). Manajemen Pemasaran, Edisi 12 Jilid 1 Satu. Jakarta: Indeks.
Kotler, P., \& Lane, K. K. (2009). Marketing Managent, edisi 13. Jakarta: Erlangga.

Kusuma, Y. S. (2014). Pengaruh brand experience terhadap brand loyalty melalui brand satisfaction dan brand trust Harley Davidson di Surabaya. Jurnal Strategi Pemasaran, 2(1), 1-11.

Mahalli, A. M., \& Hasbullah, A. R. (2004). Hadis-hadis muttafaq'alaih: bagian munakahat dan mu'amalat. kencana , 96-97.

N, S. A., T, S., \& Tresnati, R. (2015). Pengaruh Komunikasi Pemasaran Terhadap Minat Nasabah Tabungan Ib Maslahah. Prosiding Hukum Ekonomi Syariah, 67-73.

Shimp, T. A. (2003). Periklanan Promosi Aspek tambahan komunikaSI terpadu, edisi kedua. jakarta: erlangga.

Tjiptono, F. (2008). Pemasaran Strategik Edisi Satu. Yogyakarta: Andi.

wahjono, S. I. (2010). Manajemen Pemasaran Bank. Jogyakarta: Graha Ilmu.

Yuliana, R., Hidayat, A. R., \& Tresnati, R. (2016). Pengaruh Bauran Pemasaran Islami (Islamic Marketing Mix) terhadap Peningkatan Jumlah Muzakki pada RZ Kantor Cabang Bandung Antapani. Prosiding Hukum Ekonomi Syariah, 725-731.

Yusanto, M. I., \& Widjajakusuma, M. K. (2012). Menggagas Bisnis Islai. Jakarta: Gema. 